\title{
資産価値を踏まえた道路斜面防災 マネジメント手法に関する研究
}

\author{
関口 信康 $1 \cdot$ 大津 宏康 2 \\ 1正会員 パシフィックコンサルタンツ(株) （†541-0052 大阪市中央区安土町二丁目3番13号） \\ E-mail: nobuyasu.sekiguchi@os.pacific.co.jp \\ 2正会員 京都大学教授 大学院工学研究科都市社会工学専攻（†615-8540 京都市 西京区 京都大学桂） \\ E-mail: ohtsu.hiroyasu.6n@kyoto-u.ac.jp
}

\begin{abstract}
現在の厳しい経済社会情勢において道路斜面管理の予算が削減される中，道路防災総点検において対策が 必要と判断された膨大な数の要対策斜面への対応が滞っており，道路斜面の効率的な管理のあり方が問われ ている。一方，インフラストラクチャ（以下，インフラと略す）の適切な管理に向け橋梁や舗装, トンネル 等の維持管理計画が個別に策定されているが，これらの各施設は単独で機能を果たすのではなく道路ネット ワークとして安全・安心な交通機能を果たすことから，道路をネットワークとして評価することで道路斜面 を効率的に管理する必要がある。このような観点から，本研究では道路斜面の維持管理・防災対策の実施状 況，対策の効果を資産価值の視点から道路ネットワークとして評価するマネジメント手法について提案する。
\end{abstract}

Key Words : asset value, slope risk, road network, managerial accounting, project priority

\section{1. はじめに}

近年の我が国では台風，集中豪雨等による斜面災害が 多発しており，限られた予算の中で，明日にでも起こり うる斜面災害に対し，被害を最小限に止めることの重要 性が再認識されている。しかしながら，現在の悠しい経 済社会情勢において道路斜面の管理に対する予算が削減 される中，道路防災総点検において対策が必要と判断さ れた膨大な数の要対策斜面への対応が滞っているのが現 状である.こうした状況の中，道路斜面の適切な管理に よって道路のサービス水準を確保し, 自動車走行の安 全・安心を向上させるためには，サービス水準の低下に よる社会的損失を適切に評価し，優先度の高い斜面から 維持管理・防災対策を着実に実施していく必要がある.

一方，インフラの老朽化に対する適切な管理に向け, 施設の長寿命化を図ることによって道路交通の安全・安 心を確保するため, 道路橋の長寿命化修繥計画や舗装, トンネル等の維持管理計画が個別に策定され，施行され ている. しかしながら, 道路斜面, 橋梁, 舗装, トンネ ル等の道路を構成する各施設は単独で機能を果たすので はなく, 道路ネットワークとして安全・安心な交通機能 を果たすことから，道路をネットワークとして評価する
ことで道路斜面を効率的に管理する必要がある.

効率的な道路の管理に向けては，道路施設の維持管理 にリスク評価の手法を用いることで複数工種（舗装，橋 梁，危険斜面）における対策必要性を一元的に定量評価 し，道路ネットワーク全体のリスクを効率的に減少させ る管理手法が提案されている1).

また，道路舗装について，インフラのサービス水準が 適切に維持補修されていることを貸借対照表上に明記で きるような管理会計システム，繰延維持補修会計に基づ いた道路舗装管理会計システムが提案されている2). し かしながら，道路斜面の管理について，資産価值を踏ま えた管理会計的な視点から，道路斜面の維持管理・防災 対策の実施状況，対策の効果を検討した事例は，筆者の 知る限りでは存在しない.

このような状況を踏まえ, 本研究では道路斜面防災を 対象に, 以下に示古視点から道路斜面の維持管理・防災 対策の実施状況，対策の効果を評価する手法はいかにあ るべきかについて提案する.

(1道路のネットワーク性の優劣を評価する指標の一つで ある “道路が通行不能になった場合の迂回に伴う利用者 損失”を用いて道路をネットワークとして評価する.

(2)“迂回に伴う利用者損失”の算定にあたっては, 降雨 
ハザードを対象とし，降雨パターンの違いによる斜面毎 の年間破壊確率を考慮する.

(3)上記損失の裏返しとなる “道路が通行可能なことによ り生み出される経済的な便益”を道路斜面の資産価值と 捉え，管理会計的なアプローチから道路斜面の管理状況 を評価する。

\section{2. 道路の機能面から見たの資産価値}

\section{（1）道路の機能とその役割}

道路斜面は各斜面が単独で機能を果たすのではなく, 橋梁や路面 (舗装)，トンネル等，道路を構成する他の 施設と一体となって道路ネットワークとして安全・安心 な交通機能等を果たしている（表一1）。

一方，国際公会計基準では，資産を「過去の事象の結 果として報告主体が支配する資源であり，かつ，将来の 経済的便益またはサービス提供能力が当該主体に流入す ることが期待される資源をいう」と定義している゙3.こ れより, 資産価值とは, 将来の経済的便益またはサービ 又提供能力であり，道路斜面においては道路の機能とそ の役割に応じて生み出される経済的便益が資産価值であ ると考えられる.

本論では，管理会的なアプローチから道路斜面の管理 状況を評価する手法を検討するに際して, 議論を極力単 純化するために, 道路の交通機能 (トラフィック機能) に着目寸る．また，道路斜面を対象とするため，交通機 能（トラフィック機能）が中心となる道路斜面が多数存 在する地域の幹線道路等を想定した場合の検討を行う.

\section{（2）道路斜面の資産価値}

例えば，河川堤防を考えた場合，その機能と役割は主 に降水の海への放流であり, 河川断面（空間）の大きさ が資産価值であると考えられる，よって，河川堤防の資 産価值は堤防の形状（護岸勾配の違い）でその大きさが 異なることになる.

一方, 道路斜面が多数存在する地域の幹線道路等を想 定した場合, 道路の機能は交通機能（トラフィック機 能）が中心であり “路面上部空間（建築限界の空間）の 大きさ”が道路斜面を含む道路の資産価值となる.

表-1 道路の機能と役割

\begin{tabular}{|l|l|l|}
\hline \multicolumn{2}{|c|}{ 機 能 } & \multicolumn{1}{c|}{ 役 割 } \\
\hline \multirow{2}{*}{ 交通機能 } & トラフィツク機能 & ·自動車や自転車等の通行サービスの役割 \\
\cline { 2 - 4 } & アクセス機能 & $\begin{array}{l}\text { ·沿道の土地·建物への出入りサービスの役割 } \\
\text { ·間接的効果として土地利用誘導 }\end{array}$ \\
\hline \multirow{2}{*}{ 市街地形成機能 } & $\begin{array}{l}\text { ·都市の骨格を形成し, コミュニティや良好な街 } \\
\text { 区を形成 }\end{array}$ \\
\hline \multirow{2}{*}{ 空間機能 } & 都市施設収容空間 & $\begin{array}{l}\text { ·電気, ガス, 上下水道, 共同溝, 地下鉄, その } \\
\text { 他都市施設の収容空間 }\end{array}$ \\
\cline { 2 - 3 } & $\begin{array}{l}\text { ·防災通路, 火災延焼の遮断空間, 地震時の緊 } \\
\text { 急輸送路などの防災空間 }\end{array}$ \\
\hline
\end{tabular}

よって, 道路斜面の安全性（斜面崩壊が発生する可能 性）が同じであれば，形状（斜面勾配の違い）による資 産価值の差異はないと考えられる（図一 1)。

ただし，道路斜面の特性（斜面勾配や物性值の差異）

は，道路斜面の崩壞により道路が通行不能になることに よって, 道路斜面本来の資産価值が減少する（後述する 資産減耗）ことへの評価等に影響することになる.

\section{3. 道路の要求性能から見た資産価値}

\section{（1）道路の要求性能}

道路の要求性能を整理すると表一 2 のとおりであり, それぞれの要求性能を満たすことにより生み出される価 值が存在すると考えられる.

\section{（2）道路斜面の資産価値}

\section{a) 道路の安全性から評価した資産価値とは}

道路の安全性から評価した資産価值とは，道路の安全 性，走行の安全性が確保されていることに対する価值で ある. 言い換えれば，道路の交通機能（トラフィック機 能）を果たすために必要な路面上部空間の確保に要する 価格（費用）（ ○斜面を含む道路の建設費等）が道路 の安全性から評価した資産価值であると考えられる。

\section{b）道路の使用性から評価した資産価値とは}

道路の使用性から評価した資産価值とは, 道路を利用 することによって生み出される価值である. 言い換えれ ば，路面上部空間が確保されることによって生み出され
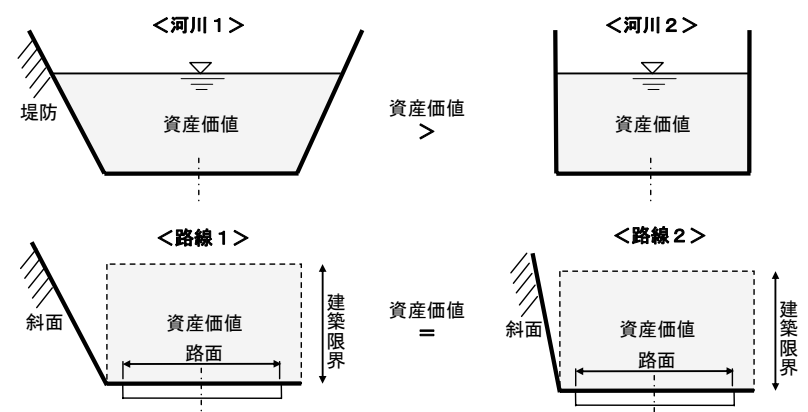

図-1 資産価值の比較

表-2 要求性能と資産価值

\begin{tabular}{|c|c|c|}
\hline 要求性能 & 内 & 価 \\
\hline 安 全 性 & $\begin{array}{l}\text { 想定されるすべての作用のも } \\
\text { とで、道路が利用者や周辺の } \\
\text { 人々の生命を努かさないため } \\
\text { に保有すべき性能。 } \\
\end{array}$ & $\begin{array}{l}\text { 道路の安全性、走行の安全 } \\
\text { 性を確保している価値 }\end{array}$ \\
\hline 使＼cjkstart用 & $\begin{array}{l}\text { 想定されるすべての作用のも } \\
\text { とで利用者や周辺の人々が道 } \\
\text { 路を使用するための性能。 }\end{array}$ & $\begin{array}{l}\text { 道路を利用することによって } \\
\text { 生み出される価値 }\end{array}$ \\
\hline 快 適 性 & $\begin{array}{l}\text { 利用者や周辺の人々が道路を } \\
\text { より快適に使用するための } \\
\text { サービス性能。 }\end{array}$ & 道路の持つ付加的な価値 \\
\hline
\end{tabular}


る経済的な便益，裏返せば道路が通行不能になった場合 の利用者の損失（利用者損失 $=$ 迁回損失 $($ 時間費用十走 行費用)）であると考えられる.

\section{4. 資産価値の評価手法}

\section{（1） 道路斜面の資産価値評価}

道路斜面の維持管理・防災対策の実施状況，対策の効 果等，道路斜面の管理状況を管理会計的なアプローチか ら道路ネットワークとして評価する場合，道路斜面の資 産価値は，前述した道路の使用性から評価した資産価値 を用いることが適切であると考えられる。

道路斜面の資産価值をその使用性から評価した資産価 值である “路面上部空間の大きさ”，即ち “路面上部空 間が確保されることによって生多出される経済的な便 益”と捉えた場合，資産価值の大きさは，その裏返しと なる “道路が通行不能になった場合の迂回に伴う利用 者損失”として式(1)で算定する．なお，利用者損失に ついての具体的な算定方法については，既往研究4,5によ り示されている方法を援用する.

資産価值 (Asset value) $\Leftrightarrow$ 利用者損失(C1)

$$
=\text { 迁回損失 (時間費用十走行費用) }
$$

なお，前述したとおり，道路斜面を含む道路の資産価 值は，道路斜面の形状（斜面勾配の違い）による差異は ないと考えられる．よって，道路斜面の資産価值を評価 する際には，個々の斜面が崩壊した場合に道路が通行不 能となる期間の利用者損失（迂回損失）ではなく，ネッ トワークとして複数の施設が存在する道路が，通行不能 となる単位期間当たりの利用者損失を採用すべきである。

しかしながら，この単位期間の設定に際しては，道路 のネットワークに存在する他の施設（橋梁や舗装, トン ネル等）が機能停止した場合に通行不能となる期間など を総合的に判断して決定する必要があるが，現状ではそ の方法論が確立されておらず，今後の課題である.

よって，本検討では暫定的な措置として，道路区間に 存在する斜面の利用者損失の内，最も大きい值（最も通 行不能となる期間が長い斜面の迁回損失）をその評価区 間における道路斜面の資産価値として採用する（図一 2）。ただしこの方法を採用した場合，道路斜面の資産

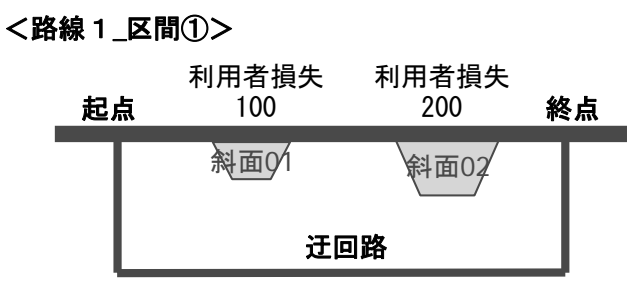

資産価值 $=200$

図-2 道路斜面の資産価值
価值が，その斜面崩壊の復旧に要する期間に影響を受け るため，斜面が崩壊した場合の復旧期間が長い程，資産 価值が大きくなる点に留意が必要である

\section{（2）資産価値の評価区間}

道路の種別を生活道路，準幹線道路と幹線道路に区分 した場合，生活道路は住宅地等の交通を準幹線道路一集 散する道路，準幹線道路は生活道路からの交通を幹線道 路へ集散する道路と位置付けられる，交通機能（トラフ イック機能）が中心となる道路斜面が多数存在する地域 の幹線道路等を想定した場合，資産価值を評価する際に は以下の点に留意する必要がある.

(1) “道路が通行不能になった場合の迂回に伴う利用者損 失”を評価するには，迁回路が同じ区間を一つの評価区 間とする必要がある.

(2)また，迂回に伴う利用者損失に影響する交通量が同じ 区間を一つの評価区間とする必要がある.

よって，資産価值の評価区間は，迂回路となる準幹線 道路と接続する区間（交通量が同一となる区間）が相応 しいと考えられる（図-3）。

\section{5. 資産減耗の評価手法}

\section{(1) 減耗評価の手法}

資産の減耗を評価する手法としては，(1減価償却会計， (2)更新会計，(3)繰延維持補修会計の3つが想定される. 繰延維持補修会計では，道路斜面の維持管理・防災対 策に必要となる対策費を算出し，各期に必要対策費引当 金として計上する。

また，必要対策費引当金と実際に支出した対策費（対 策費実績）の差額を“負債又は負の資産”である繰延対 策費引当金として計上するものである.

減価償却会計では，資産を取得した費用を供用期間に 割り振るが，繰延維持補修会計では，資産を使用したこ とで維持管理・防災対策が必要になると考え，その対策 費を供用期間に割り振ることになる.

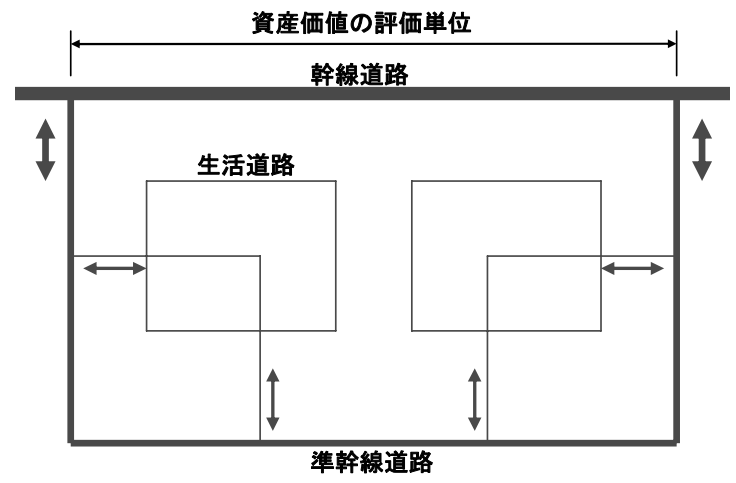

図-3＼cjkstart資産価值の評価区間 
本研究では，以下の理由から資産減耗の評価手法とし て，繰延維持補修会計を採用する.

・必要対策費引当金と実際に支出した対策費（対策 費実績）の差額（繰延対策費引当金）を確認する ことで, 必要な対策が実施されたかどうかを，会 計情報として評価することが出来る.

・繰延対策費引当金の残高を確認することで，資産 価值減少を会計情報として評価することが出来る

・上記から，維持管理・防災対策の実施状況と資産 価值増減との関係を, 会計情報として評価するこ とが出来る.

ただし本研究では，道路斜面の資産価値として，道路 の安全性から評価した資産価值（三斜面を含む道路の建 設費等）ではなく，道路の使用性から評価した資産価値

$($ 利用者損失 $=$ 迂回損失 $($ 時間費用十走行費用) $)$ を採用 している.

よって, 繰延維持補修引当金の残高ではなく, 道路斜 面の性能低下に伴い減少寸る資産価值，すなわち維持管 理・防災対策が行われなかった事実（実際に支出されな かった対策費）に伴い残存する “斜面が崩壊した場合の 利用者損失”を資産価值の減少 (資産の減耗) として評 価することになる。

\section{（2）減少資産価値の評価}

道路斜面の維持管理・防災対策において，対策が実施 されなかった場合の資産価値の減少は, 斜面の性能低下 を考慮した “斜面が崩壊した場合の利用者損失” である 斜面リスク額（年間リスク）を算定することで評価する. 道路斜面防災の分野において筆者ら でに道路に隣接する斜面の補強対策を対象として, 斜面 崩壊により発生する損失の評価に基づく, リスク管理手 法について検討を進めてきた.「斜面リスク評価システ ム」は，これまでの筆者らの研究の知見に基づき，降雨 ハザードを対象とした道路斜面の崩壊により発生する社 会経済学的損失の評価に基づくリスク評価手法を用いた 意思決定の支援ツールとして, 斜面諸元の自動取得, 降 雨時における斜面毎の破壊確率の算定，迂回損失に基づ く道路ネットワークのリスク評価などの解析システムを GIS上にパッケージ化したものであり，このシステムを 用いて斜面リスク額を算定する。 ${ }^{11), 12,13)}$ (図一-4).

「斜面リスク評価システム」において，降雨ハザード による斜面の年間破壞確率は，式(2)に示寸長大斜面に おける安定解析法を援用した性能関数を用い，強度係数

$(\tan \phi d, C d)$ を確率変数として, これらの変動係数（標 準偏差/平均值）毎に 1 次近似 2 次モーメント法

（FOSM）を用いて降雨時の破壊確率 $P_{f}$ を求める方法を 採用している.

$$
Q=\left(1-\frac{\gamma_{w} H_{w}}{\gamma H}\right) \cdot \frac{\tan \phi d}{\tan \alpha}+\frac{C d}{\gamma H} \cdot \frac{1}{\sin \alpha \cos \alpha}-1
$$

ここに，Qは性能関数， $\gamma_{w}$ は水の単位体積重量，忙 土の単位体積重量, $\phi d$ は土の内部摩擦角, $C d$ は粘着力, また $\alpha$ は無限斜面の傾斜角, $H$ は崩壊土の層厚, $H_{w}$ は崩 壊土中の水深である. 降雨による斜面毎の年間破壊確率 は，式(3)に示す通り想定降雨レベル $(\alpha)$ 毎に得られた条 件付き破壊確率 $p(\alpha)$ に，その降雨レベルが一年間に発 生する可能性を重みづけした形で合積している.

$$
P_{a}=\int_{0}^{\infty} p_{f}(\alpha) \cdot \frac{d P(\alpha)}{d \alpha} \cdot d \alpha
$$

ここに, $P(\alpha)$ は降雨の発生確率, $p(\alpha)$ は条件付き破壊 確率, Paは年間破壊確率である.

また，斜面の年間破壊確率の算定にあたっては，降雨 時の斜面内地下水位を予測 (3 連 1 次元タンクモデル)

し, 降雨パターン（前方集中型・中央集中型・後方集中 型）の違いによる年間破壊確率を算定することで，最も 危険な状態となる降雨パターンを評価している. この方 法の詳細については, 既往文献 実測期間における降雨を入力して得られた再現水位と実 測地下水位を比較し, 水位予測の再現性についての妥当 性が検証されており，参考にされたい．

各斜面における年間リスクは，年間破壊確率 $(P a)$ と損 失額 $(C i)$ をもとに算出する.

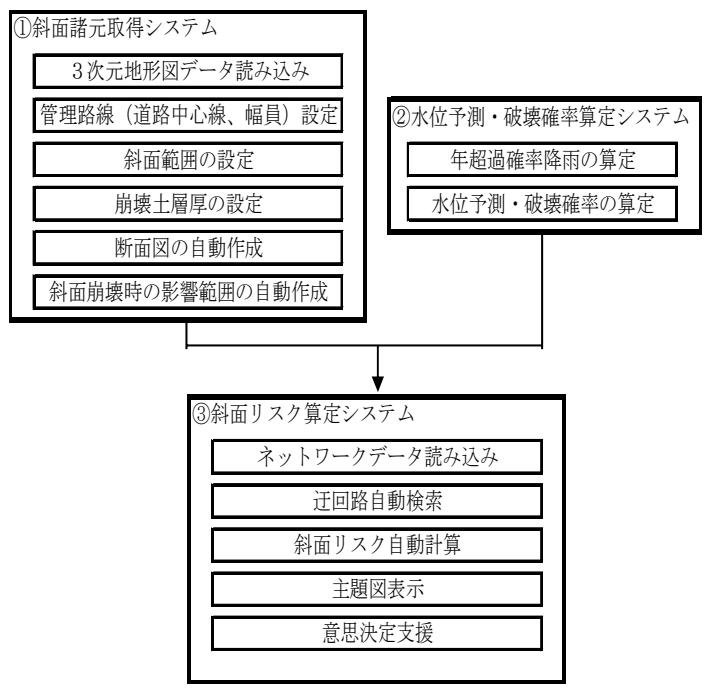

図-4 斜面リスク評価システムのシステム構成

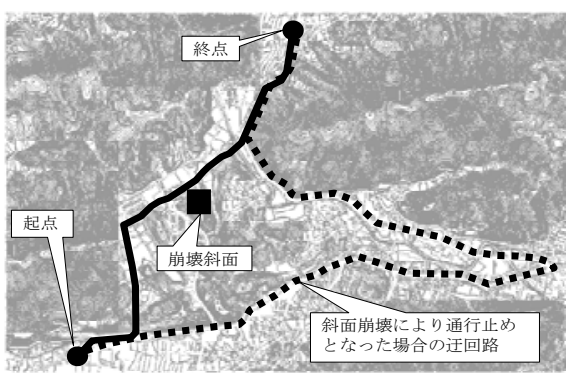

図-5 迂回路の自動検索 
年間リスク $R a=$ 年間破壊確率 $P a \times$ 損失額 $C i$

損失額は，斜面が崩壊した場合の迂回路を自動検索す ることで，直接的損失である管理者損失と間接的な迂回 路等の利用に伴う利用者損失を算定しており，各損失額 についての具体的な算定方法については, 既往研究4,5に より示されている方法を援用している（図一5）。

利用者損失 $(C 1)=$ 迂回損失

$$
\text { (時間費用十走行費用) }
$$

管理者損失=通行車両,搭乗者に対する損失 $(C 2)$

$$
\text { 十復旧費用 }(C 3)
$$

損失額 $(C i)=C 1+C 2+C 3$

なお，本研究では道路斜面の資産価值として，道路の 使用性から評価した資産価值（利用者損失 $=$ 过回損失 (時間費用十走行費用)）を採用するため，管理者損失は 考慮していない。

\section{6. 管理状況把握のための資産価値評価の試行}

\section{（1）道路斜面の資産価值評価の試行}

交通機能（トラフィック機能）が中心となる道路斜面 が多数存在する地域の幹線道路について，実際の路線に おける 3 区間を抽出し，道路斜面の資産価值を “道路が 通行不能になった場合の迁回に伴う利用者損失”として 算定した（図一6）。ただし，各区間における資産価值 は，斜面が崩壊した場合の利用者損失の最大值を道路斜 面の資産価值として採用している（表一 3 ）。

\section{（2）減少資産価値の評価の試行}

道路斜面の資産価值を評価した 3 区間について，区間 内に存在する道路斜面の性能低下に伴い減少する資産価 值（DV: Decrease asset value）を「斜面リスク評価システ ム」を用いて式(8)で算定した.

性能低下に伴う減少資産価值 $(D V)$

$$
=\text { 資産価值 }(\mathrm{C} 1) \times \text { 年間破壊確率 }(\mathrm{Pa})
$$

各斜面の性能低下に伴い減少寸る資産価值は，資産価 值（損失額）と年間破壞確率の積である斜面リスク（斜 面における年間リスク）として算定している. よって, 斜面リスクは必要となる道路斜面の維持管理・防災対策 が実施されるまで，資産価值の減少という会計情報とし て毎年，計上されることになる.（表一-4）。

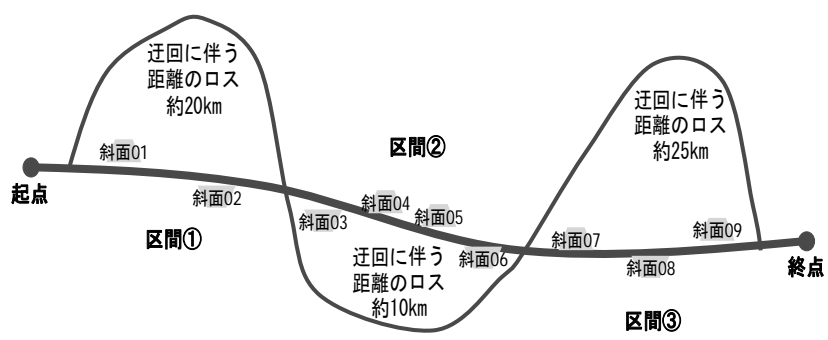

図-6 評価区間の概要

\section{（3）資産価値評価に基づく事業実施優先度評価の試行}

事業実施の優先度を評価寸る指標としては，道路斜面 の性能低下に伴い減少する資産価値 $(D V)$ を直接用い ることも考えられる（減少資産価值の大きいものから， 優先的に対策事業を実施する）。

しかしながら，限られた予算の中で，道路斜面の維持 管理・防災対策を実施するには，事業実施の効率性とい った視点も踏まえて評価することが重要となる．よって， 道路斜面の性能低下に伴い減少する資産価值 $(D V)$ を 用い，資産価值復元の効率性（E：Efficiency）を式(9)か ら算定することで，資産価值の視点から斜面に掛かる対 策工費を考慮した事業実施優先度を評価する（表一 5 ）。

資産価値復元効率性 $(E)$

$=$ 性能低下に伴う減少資産価值 $(D V)$ 薋産価値復元のための対策工費 $(C 4)$

\section{（4）管理状況把握のための資産価値評価の試行}

\section{a) 斜面防災会計シート}

道路斜面の維持管理・防災対策の実施状況，対策の効 果を資産価值の視点から道路ネットワークとして評価す るため，管理会計的なアプローチから道路斜面の管理状 況を評価する斜面防災会計シートを作成した（表一 6 ，

\begin{tabular}{|c|c|c|c|}
\hline 区間No. & 斜面No. & 損失額 (千円) & 資産価値 (千円) \\
\hline 区間(1) & 钭面01 & $\frac{1,034,718}{202020}$ & $1,034,718$ \\
\hline \multirow{3}{*}{ 区間(2) } & 斜面03 & 943,925 & \multirow{3}{*}{$1,564,392$} \\
\hline & 斜面 04 & 140,368 & \\
\hline & $\frac{\text { 斜面 } 05}{\text { 斜面06 }}$ & $\begin{array}{r}1,564,392 \\
174,952\end{array}$ & \\
\hline \multirow{3}{*}{ 区間(3) } & 斜面 07 & $1,485,553$ & \multirow{3}{*}{$1,485,553$} \\
\hline & 斜面08 & $1,142,733$ & \\
\hline & 斜面 09 & $1,073,353$ & \\
\hline
\end{tabular}
表-7).

表-3 資産価値の評価結果

\begin{tabular}{|c|c|c|c|c|}
\hline 区間No. & 斜面No. & 損失額 (千円) & 年間破壊確率 & 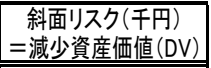 \\
\hline \multirow{2}{*}{ 区間(1) } & 斜面01 & $1,034,718$ & 0.013 & 13,594 \\
\hline & 斜面 02 & 223,320 & 0.000 & 0 \\
\hline \multirow{4}{*}{ 区間(2) } & 斜面 03 & 943,925 & 0.058 & 54,871 \\
\hline & 斜面04 & 140,368 & 0.099 & 13,961 \\
\hline & 斜面 05 & $1,564,392$ & 0.090 & 140,208 \\
\hline & 斜面 06 & 174,952 & 0.014 & 2,458 \\
\hline \multirow{3}{*}{ 区間(3) } & 斜面 07 & $1,485,553$ & 0.019 & 27,853 \\
\hline & 斜面 08 & $1,142,733$ & 0.020 & 22,532 \\
\hline & 斜面09 & $1,073,353$ & 0.009 & 9,203 \\
\hline
\end{tabular}

表-4 減少資産価值の評価結果

\begin{tabular}{|c|c|c|c|c|c|}
\hline 区間№. & 斜面№. & 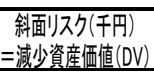 & 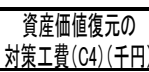 & $\begin{array}{l}\text { 資産洒洒復元 } \\
\text { 効率性(E) }\end{array}$ & 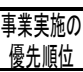 \\
\hline \multirow{2}{*}{ 区間(1) } & 斜面1 & 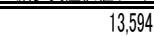 & $\begin{array}{ll}37,08\end{array}$ & $\begin{array}{ll}0.367 \\
\end{array}$ & \\
\hline & 鈄面02 & & 9,39 & & \\
\hline \multirow{4}{*}{ 区間(2) } & 鈄面03 & 54,871 & 92,84 & 0.591 & \\
\hline & 钭面04 & 13,961 & 13,71 & $\frac{1.018}{1.018}$ & \\
\hline & 斜面05 & 140,208 & 123,03 & 1.140 & \\
\hline & 銯面06 & 2,458 & 17,25 & $\overline{0.142}$ & \\
\hline \multirow{3}{*}{ 区間(3) } & 銯面07 & 27,853 & 72,76 & 0.383 & \\
\hline & 耕面08 & 22,532 & 56,01 & 0.402 & \\
\hline & 斜面09 & 9,203 & 52,50 & 0.175 & \\
\hline
\end{tabular}

表-5 事業実施優先度の評価結果 
道路斜面の資産価值を評価した 3 区間について，事業 実施優先度の高い順に斜面の維持管理・防災対策を実施 した場合（以下，優先度評価案と略す）における今後10 年間（2012年度～2021年度）の会計情報を記載した会計 シートを表一 6 に，事業実施優先度に関係なく対策を実 施した場合（以下，無計画案と略す）の会計シートを表 -7 に示寸．会計シートにおいて，B～D列は資産に関 する会計情報， E O 列は費用に関する会計情報，P～Z 列は負債又は負の資産に関する会計情報を提供している.

\section{b) 資産に関する会計情報（B～D列）}

会計シートにおける資産の部では，まず道路斜面の資 産価値を評価した結果を，建設当初の資産価値として 4 行目に計上寸る. 次に各期の行の上段には負債の部 $(\mathrm{P}$ ～Z列）で計上した減少資産価值を建設当初の資産価值 から控除した当期末の資産価值を計上寸る.

また，各期の行の下段には資産状況を式(10)から算定 することで，道路斜面の維持管理・防災対策を実施した 場合（又は実施できなかった場合）の資産価值の状況を 記載し施策の効果を検証する。

表-6 斜面防災会計シート（事業実施優先度の高い順に対策を実施した場合）

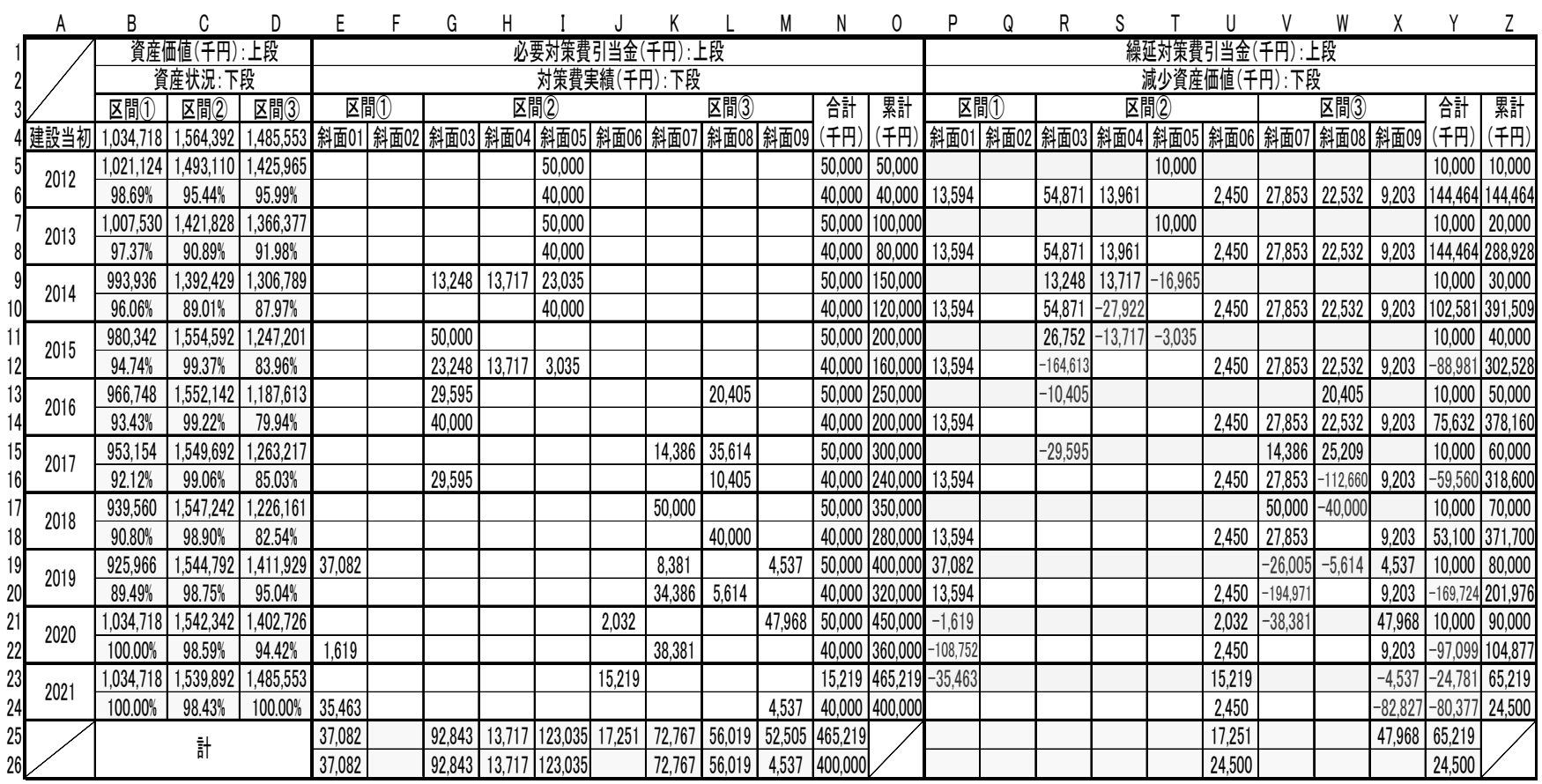

表-7 斜面防災会計シート（事業実施優先度に関係なく対策を実施した場合）

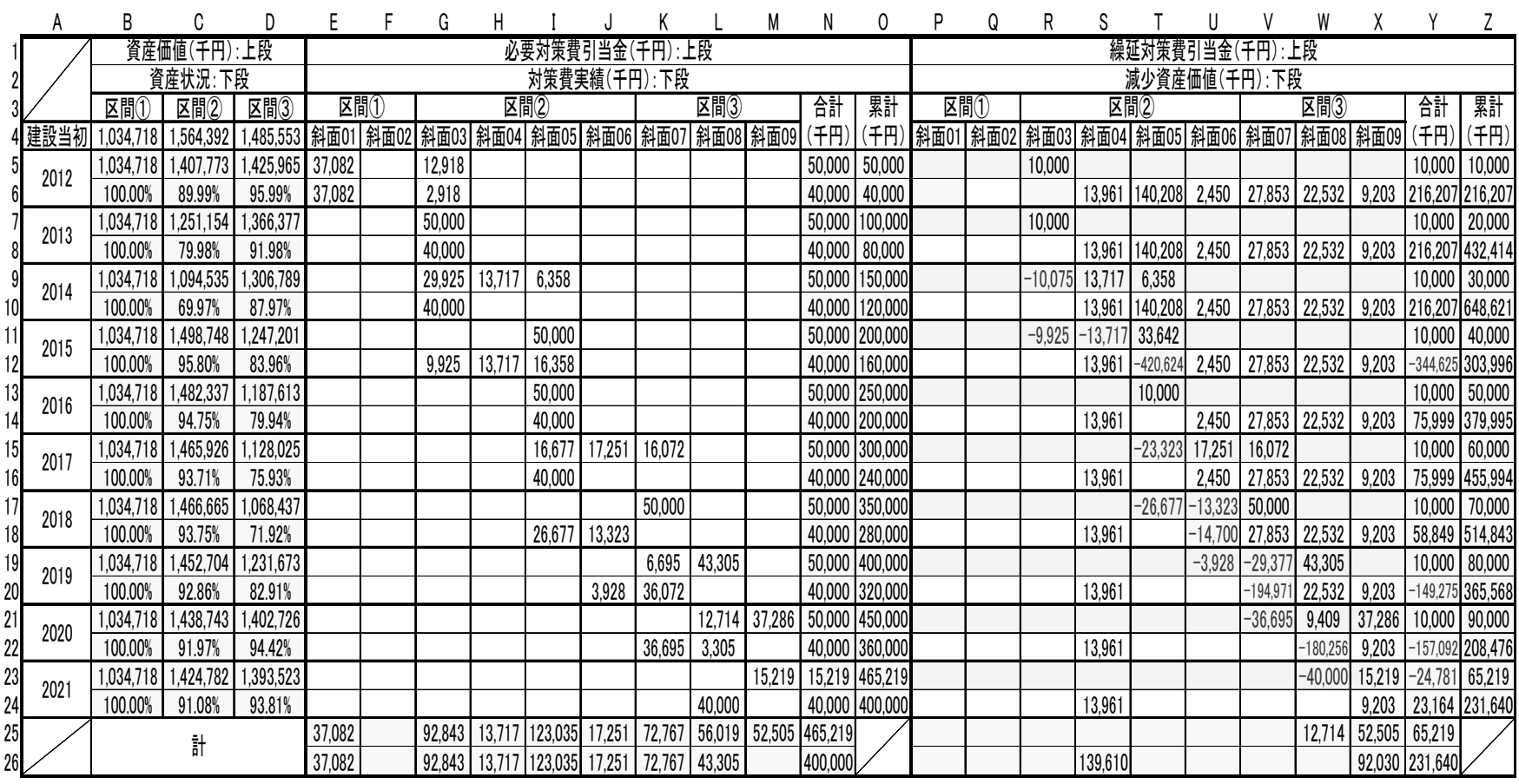




\section{資産状況(\%)=当期末の資産価值}

$$
\div \text { 建設当初の資産価值 } \times 100
$$

例えば，優先度評価案（表－6）と無計画案（表一 7）の資産状況を比較すると，無計画案では区間(2)の資 産状況が約70\%，区間(3の資産状況が約72\%まで低下寸 る状況が生じており，事業実施優先度を適切に評価し， 優先度の高い斜面から維持管理・防災対策を着実に実施 していくことの重要性が確認できる.

なお，建設当初の資産価値については，その区間の重 要度を評価する指標としても活用可能である.

\section{c） 費用に関する会計情報（E〜O列）}

会計シートにおける費用の部では，まず今後10年間に おける道路斜面の維持管理・防災対策の計画を策定し， 各期の行の上段に計画した対策費を必要対策費引当金と して計上する. 次に各期の行の下段には実際に支出した 対策費（対策費実績）を計上し，道路斜面の維持管理・ 防災対策の実施状況（計画と実施の差）を確認する。

また，必要対策費引当金の合計（25行目）と対策費実 績の合計（26行目）を比較することで，対策が未実施で ある区間，斜面を確認することが出来る.

なお，本会計シートにおいては，予算計画上の年間対 策費を50,000千円，実際に支出した年間対策費を40,000 千円と設定して，各費用を計上している.

\section{d) 負債に関する会計情報（P～Z列）}

会計シートにおける負債の部では，まず各期の行の上 段に，費用の部で算定した必要対策費引当金と対策費実 績の差額を繰延対策費引当金として計上することで，対 策の実施状況（繰延対策費引当金がプラスの場合，対策 の未実施箇所有り）を確認することが出来る.

次に各期の行の下段には，実際に対策が実施されるま で減少資産価值を毎年計上し，建設当初の資産価值に対 する資産価值の減少（資産の減耗）を評価する，ただし 対策が実施された場合には，それまで計上してきた減少 資産価值の累計を，その期にマイナス計上寸ることで, 資産価值が復元されたことを表現する.

よって, 繰延対策費引当金の合計（Y列および25行 目）や累計（Z列）を見ることで，道路斜面の維持管 理・防災対策の実施状況や今後必要となる対策費を確 認・評価することが可能である．また，減少資産価值の 合計（Y列および26行目）や累計や（Z列）を見ること で，資産価值の減耗を評価することが可能である.

\section{（5）他の施設への適用性}

本論では道路斜面を対象に，施設の管理状況を評価す る手法について提案した。しかしながら, 道路斜面は, 橋梁，舗装，トンネル等，同一の道路ネットワーク上に
存在する他の施設と一体となってその機能を果たすこと から, 道路を構成する他の施設と総合的に評価する必要 がある．例えば，区間(1)の斜面03と区間(3)橋梁01のど ちらを優先して対策すべきか等，異なる施設間の事業実 施の優先度を評価するための共通の指標が必要となる.

本論で提案した会計シートを用い，道路斜面をはじめ， 橋梁, 舗装, トンネル等の対策シナリオの組合せをシミ ユレーションし，“道路が通行不能になった場合の迂回 に伴う利用者損失”という共通指標を用いて施策の効果 を検証することで，異なる施設間の事業実施の優先度を 評価することが可能であると考えられる.

\section{7. まとめ}

本研究では道路斜面防災を対象に, 道路斜面の維持管 理・防災対策の実施状況，対策の効果を，資産価值の視 点から道路ネットワークとして評価する手法, 管理会計 的なアプローチから道路斜面の管理状況を評価するマネ ジメント手法について提案した.

しかしながら，道路を構成する各施設を資産価值の視 点から道路ネットワークとして評価し, 効率的・効果的 な道路施設の維持管理を実現するためのマネジメント手 法を提供するには，今後以下の点について検討を深める 必要がある.

\section{a）道路の他の機能を評価した資産価値}

道路の機能としては, 交通機能 (トラフィック機能) 以外に, 交通機能（アクセス機能），市街地形成機能， 空間機能（都市施設収容空間，防災空間）があげられる。 道路の資産価值評価にあたっては，道路種別（生活道 路, 準幹線道路及び幹線道路）や周辺土地利用との関連 （地価）も踏まえ，交通機能（トラフィック機能）以外 の機能も含めた評価手法について検討寸る必要がある.

\section{b）道路の使用性から評価する資産価値の範囲}

本検討にあたっては, 道路のトラフィック機能に着目 し, 道路の使用性から評価した資産価値として利用者損 失 (=迁回損失(時間費用十走行費用) ) を採用した。 し かしながら，道路施設全体の評価にあたっては，管理者 損失（二通行車両,搭乗者に対寸る損失十復旧費用）等, 他の評価項目をどの範囲まで含めるべきかについて検討 する必要がある。

\section{c）道路施設全体の管理会計的な評価手法}

道路を構成する各施設を資産価值の視点から道路ネッ トワークとして評価するにあたっては, 斜面防災会計シ 一トを他の施設に拡張した具体的な評価手法を構築する 必要がある。 


\section{参考文献}

1) 杉浦聡志，金森吉信，高木朗義，倉内文孝，森本博 昭：リスク評価に基づいた道路施設の総合維持管理 手法の開発，土木学会論文集 F4（建設マネジメン 卜）, Vol.67, No.4, pp. I_103- I_112, 2011.

2) 慈道充, 江尻良, 西口志浩, 小林潔司：道路舗装管 理会計システム，繰延維持補修会計方式による試行， 京都大学サマースクールテキスト：建設マネジメン トを考える, pp.161-174, 2003.

3) 筆谷勇 : Q\&A 公会計読本一理論と実例で見る改革の 論点，株式会社ぎょうせい，2004.

4) 斜面防災研究委員会 : 斜面安定評価における劣化概 念の導入, (社)建設コンサルタンツ協会近畿支部, 2006.

5）道路投資の評価に関する研究委員会 : 道路投資の評 価に関する指針（案），日本総合研究所，1998.

6) 大津宏康, 大西有三，水谷守：高速道路に近接する 斜面を対象とした自然災害に対するリスクマネジメ ント手法に関する提案，土木学会論文報告集，土木 学会論文集, No.658/VI-48, pp.245-254，2000。

7) 大津宏康, 大西有三，水谷守，伊藤正純：地震に伴 う災害リスク評価に基づく斜面補強の戦略的立案方 法に関する一提案，土木学会論文集，No.679/VI-51, pp.123-134, 2001.
8) 大津宏康, 大西有三, 西山哲, 竹山雄一郎：岩盤崩 落による社会経済的損失を考慮したリスク評価に関 する研究, 土木学会論文集, No.707/VI-55, pp.207218, 2002.

9）高橋健二, 大津宏康, 大西有三 : タンクモデル法を 用いた地下水位挙動を考慮した斜面リスク評価の研 究，土と基礎，No.51-10，pp.15-17， 2003.

10) 東郷智, 大津宏康, 大西有三, 伊豆隆太郎, 安田亨, 高橋健二：GIS を用いた戦略的斜面アセットマネジメ ント手法の研究, 建設マネジメント研究論文集, Vol.11, pp.141-148, 2004.

11) 関口信康, 大津宏康, 安田亨, 伊豆隆太郎, 高橋健 二：道路斜面防災統合マネジメントシステムに関す る研究, 建設マネジメント研究論文集, Vol.15, pp.141-150, 2008.

12) 関口信康, 大津宏康：道路斜面防災統合マネジメン 卜の意思決定における情報提供手法に関する研究, 建設マネジメント研究論文集, Vol.16, pp.61-70, 2009.

13) 関口信康, 大津宏康, 伊豆隆太郎 : 道路斜面防災マ ネジメントにおける事業優先度評価手法に関する研 究, 土木学会論文集 F4（建設マネジメント）, Vol.67, No.4, pp. I_121- I_130, 2011.

(2012.5.14 受付)

\section{STUDY ON ROAD SLOPE DISASTER PREVENTION MANAGEMENT BASED ON ASSET VALUE}

\section{Nobuyasu SEKIGUCHI, Hiroyasu OHTSU}

To improve the safety and security of driving while coping with today's stagnant economy and frequent natural disasters, road slopes should be appropriately managed. In order to achieve the goals, road managers should establish management methods in road slope disaster prevention by clarifying social losses that would result by drops in service levels. On the other hand, in order to manage an infrastructure appropriately, maintenance management plans, such as a bridge, pavement, a tunnel, are formulated individually. However, each of these institutions achieve a traffic function safe as a road network, and safe rather than achieve a function independently. Therefore, it is necessary to manage road slopes by evaluating a road as a network. It is important that road managers evaluate asset value of the slope in a road network to manage the road slope effectively. From this viewpoint, this study proposed "management methods based on asset value" in road slope disaster prevention, which evaluated as a road network. 